\title{
FACTORS THAT INFLUENCE THE DEVELOPMENT OF JUMIANG BEACH TOURIST AREA IN PAMEKASAN DISTRICT
}

Dewi Rupyanti Sinaga*, Rimadewi Suprihardjo**, Adjie Pamungkas**

*) Master Student, Department of Architecture, Faculty of Civil Engineering and Planning, Institute of Technology Sepuluh Nopember, Indonesia

**) Lecturer, Department of Architecture, Faculty of Civil Engineering and Planning, Institute of Technology Sepuluh Nopember, Indonesia e-mail: dew.borusinaga@gmail.com

\begin{abstract}
Jumiang Beach Tourist Area has tourism potentials that should be developed as one of the main coastal tourist areas in Pamekasan. The presence of ODTW and several diverse tourism potentials in Jumiang Beach Tourist Area may become the opportunities to further develop the tourism in Jumiang Beach. The absence of efforts to develop the utilization of tourist attraction, the lack of facilities and infrastructure supporting the tourist area, and the lack of interaction between the local community and the tourists who visit this beach indicate the absence of optimal development efforts. This article is a part of research on the formulation of the concept of development of Jumiang Beach Tourist Area in Pamekasan District. Through Content Analysis technique, the variables that influence the development of tourist areas were found. These variables were then transformed through descriptivequalitative analysis to obtain the significant influential factors. The results showed that there were 8 (eight) factors that influence the development of Jumiang Beach Tourist Area: active participation of local community in tourism activities; improvement of coastal tourist attractions by utilizing the uniqueness in each tourist potential; presence of institutional managers of tourist areas; improvement the quality of local community in supporting tourist activities; improvement the quality and quantity of tourism infrastructure and facilities; strengthening of marketing and promotion network quality; maintenance and improvement of environmental sustainability in coastal tourist area; and formulation of supporting policies related to spatial factors.
\end{abstract}

Keywords: tourism development, coastal tourism, Jumiang Beach, content analysis

\section{ABSTRAK}

Kawasan wisata pesisir Pantai Jumiang seharusnya dapat dikembangkan sebagai salah satu wisata pesisir andalan di Kabupaten Pamekasan melalui keberadaan 
ODTW (Obyek dan Daya Tarik Wisata) dan beberapa potensi wisata yang beragam. Namun belum adanya upaya pengembangan pemanfaatan daya tarik wisata, kurangnya sarana dan prasarana penunjang wisata, serta belum adanya interaksi antara masyarakat setempat terhadap wisatawan yang berkunjung mengindikasikan belum adanya upaya pengembangan yang optimal. Artikel ini merupakan bagian dari penelitian mengenai perumusan konsep pengembangan kawasan wisata pesisir Pantai Jumiang di Kabupaten Pamekasan. Melalui teknik Content Analysis dapat diketahui vaiabel-variabel yang berpengaruh terhadap pengembangan kawasan wisata, kemudian ditransformasikan melalui analisis dekriptif kualitatif untuk memperoleh faktor-faktor yang signifikan berpengaruh. Hasil penelitian menunjukkan terdapat 8 (delapan) faktor yang berpengaruh terhadap pengembangan kawasan wisata pesisir Pantai Jumiang, antara lain partisipasi aktif masyarakat dalam kegiatan pariwisata; peningkatan kualitas daya tarik wisata pesisir dengan memanfaatkan keunikan pada setiap potensi wisata; keberadaan kelembagaan pengelola kawasan wisata; peningkatan kualitas masyarakat setempat dalam mendukung kegiatan pariwisata; peningkatan kualitas dan kuantitas prasarana dan sarana penunjang kawasan wisata; penguatan kualitas jaringan promosi dan pemasaran; pemeliharaan dan peningkatan kelestarian lingkungan wisata pesisir; serta perumusan kebijakan pendukung terkait faktor spasial pengembangan kawasan wisata pesisir Pantai Jumiang.

Kata kunci: pengembangan wisata,wisata pesisir, Pantai Jumiang, Content Analysis

\section{INTRODUCTION}

Tourism activities will always be a basic need of every human being as it works as a means to eliminate the everyday boredom. Seeing the fact that human beings will always need traveling, the tourism industry will never die (Yoeti, 1985). Nature tourism is one type of tourisms whose main attraction comes from the beauty of nature, natural resources, and environmental system (Inskeep, 1991). Madura Island is an island that holds a lot of tourism potentials including natural attractions, one of which can be found in Pamekasan District.

One of the potential of nature tourism that can be found in Pamekasan is Jumiang Beach which is located at Tanjung Village, Pademawu Subdistrict. Jumiang Beach Tourist Area is a coastal tourist attraction which has a unique and different characteristic compared to other beaches in Pamekasan which are typically sloping beaches (Badan Perencanaan dan Pembangunan Daerah Kabupaten Pamekasan, 2012). Jumiang Beach has two locations, namely cliffy beach on the east side and sloping beach on the west side. In addition, there are also several other attractions such as the tomb of Buju' Adirasa who was the main historic figure of Madura Island and respected by the local community as well as the annual tradition of the coastal communities in the form of Rokat Bhumih Jumiang. However, the tourism potentials are not maximally developed due to the lack of maintenance of the quality 
and attractiveness of the tourist area. Thus, tourists who visit the beach will not any other activity instead of just enjoying the scenery.

Problem encountered in Jumiang Beach Tourist Area is the interaction between natural resources with local human resources. The local community knowledge and interest in the tourism sector is still not fully maximized. As a result, there are many untapped sources. In addition, the interaction between the local community and the tourists are also not optimal. Another problem is the lack of facilities as the tourism supporting aspects. At the first time, the buildings and facilities were well-maintained, and thus could support the comfort of the visitors. Today, these facilities lack decent treatment. Jumiang Beach Tourist Area is still not supported by good accessibility. In addition, this place is still not equipped with toilets, lodgings and culinary places to facilitate the tourists' needs (Dinas Pariwisata, Pemuda \& Olah Raga, dan Kebudayaan Kabupaten Pamekasan, 2012).

These conditions have an impact on the decreased number of tourist visits in Jumiang Beach from year to year. Actually, there was an increased number of tourist visits as many as 3,044 people in 2012 (17,701 people) to 2013 (20,745 people). However, in 2014, there was a decline of the tourist visits which reached 4,663 people. The number of tourist visits per month tends to be stagnant throughout 2014, even on the Lebaran Ketupat (Dinas Kebudayaan dan Pariwisata Provinsi Jawa Timur, 2012).

Therefore, it is necessary to know the factors that influence the development of the coastal tourist areas that are useful as the basis for the formulation of the concept of a more effective tourism development to apply in Jumiang Beach Tourist Area, in Pamekasan District. This study conducted based on the theory about aspects that affect the development of tourist area. It aimed to guide and as a measuring tools for the exploration of empirical condition of Jumiang Beach tourist area, so that can be known the factors that influence the development of Jumiang Beach tourist area.

\section{THEORY / RESEARCH METHODS}

\section{Method of Data Collection}

Data collection methods used in this study consist of primary and secondary data collection. The methods used in the primary survey are semi-structured interviews, observation, and questionnaires. Semi-structured interviews conducted for stakeholders chosen through stakeholder analysis process consisting of three (3) groups of stakeholders:

1. Stakeholders from Governance Group

a. Planning and Development Agency of Pamekasan (G1)

b. Department of Tourism, Youth and Sports Affairs, and Culture of Pamekasan (G2)

2. Stakeholders from Private Sector Group

a. Business Actors of Hospitality and Tourism in Pamekasan (P1)

b. Planning and Development Consultants in Pamekasan (P2) 


\section{Stakeholders from Civil Society Group}
a. Head of Dusun Jumiang (C1)
b. Prominent scholars in Dusun Jumiang (C2)

Meanwhile, the methods for secondary data collection are literary survey and institutional survey to get a general overview of Pamekasan district in general and a general overview of Jumiang Beach Tourist Area in particular.

\section{Method of Analysis}

Prior to the analysis of the factors that influence the development of Jumiang Beach Tourist Area, the researcher identifies the tourism potentials in the area of research. In identifying the potentials of the coastal tourist area, the inputs used are the variables that are considered able to assess the tourism potentials based on the results of the literature review. Theoretical descriptive qualitative is used for the analysis.

Furthermore, content analysis is used to analyze the factors that influence the development of Jumiang Beach Tourist Area. Content analysis is a data exploration technique that relies on the code in a recording text (Krippendorff, 2004). The content analysis in this study is done by conducting a literature review related to aspects that influence the development of the tourist area. The results of the study of the theory or literature generate 18 variables that are considered influential in the development of tourist area and become a parameter in the exploration of data and information to selected stakeholders (Table 1).

Table 1. Variables that are considered influential in development of tourist area

\begin{tabular}{cl}
\hline Code & \multicolumn{1}{c}{ Variables of Development Tourist Area } \\
\hline V1 & Types of coastal tourist attraction \\
V2 & The uniqueness of coastal tourist attraction \\
V3 & The existence of life culture \\
V4 & The uniqueness of life culture \\
V5 & Availability of supporting utilities \\
V6 & Availability of service facilities \\
V7 & Availability of transport modes to tourist area \\
V8 & Road networks \\
V9 & Local community activities associated with tourism activities \\
V10 & Local community attitudes towards tourists \\
V11 & Policies supporting the development of coastal tourist area \\
V12 & Presence of the coastal tourist area manager \\
V13 & Presence of investment opportunities for private sectors \\
V14 & Marketing strategy of coastal tourism \\
V15 & Improvement the environmental hygiene of coastal tourism \\
V16 & Improvement of human resources in the coastal tourist area \\
V17 & Proportion of people working in the tourism sector \\
V18 & The level of public welfare around the tourist area \\
\hline &
\end{tabular}


The exploration results are transformed into a transcript of the interview that will further be made into manuscript for coding (Krippendorff, 1993). The coding process uses semantic content analysis which classifies signs based on owned meaning and simplified in the tabulation using assertion analysis to show the frequency influential indications of each variable on the development of Jumiang Beach Tourist Area. The results of coding and simplification are used to understand the data by looking back at the conversational elements namely style of speech, to see the significance of the influential variables. The end result of this analysis is the narrating process in the form of abstraction results. Abstraction is done by transforming the influential variables into influential factors on the development of Jumiang Beach Tourist Area. See the following Figure 1 to get more details about the stages of Content Analysis.

\section{Unitizing $\Rightarrow$ Sampling $\Rightarrow$ Coding $\Rightarrow$ Reducing $\Rightarrow$ Inferring $\Rightarrow$ Narrating}

Figure 1. Stages of Content Analysis Source: Krippendorff, 2004

\section{RESULTS AND DISCUSSIONS}

\section{Identification of Potentials of Jumiang Beach Tourist Area}

There are 8 (eight) tourism potentials in Jumiang Beach Tourist Area, namely:

1. Jumiang Beach Natural Panorama

Jumiang Beach has a unique and different characteristic compared to other beaches in Pamekasan. This beach has steep cliffs on one side and sloping beach on the other side. On the sloping area, Jumiang Beach offers exotic landscapes of the vast sea with a direct view to the Madura Strait while on the top of the cliff, Jumiang Beach offers scenic and beautiful expanse of ocean with high cliffs on the east side and the rocks below the cliff (Figure 2).

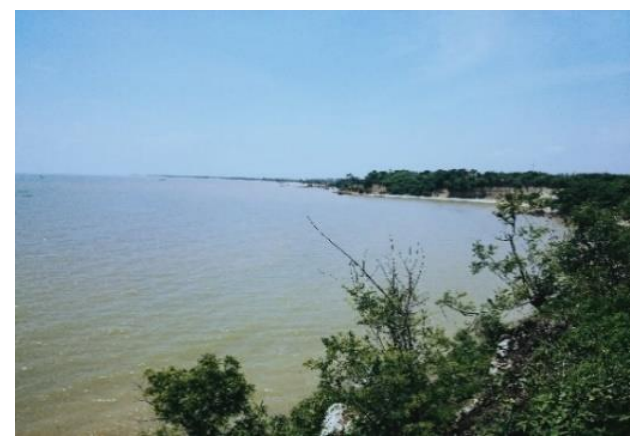

Figure 2. Jumiang Beach Natural

Panorama from The Cliffs

Source: field survey, 2015 
2. The Historical Tomb of Buju' Adirasa

This tourism spot is unique because it has a historical heritage that adds another potential of this beach. The tomb gives us a historical value that during his lifetime, Adirasa liked to meditate to get closer to the Almighty and this of course will give another value for the tourists and local community. See the following Figure 3 to get more details about The Historical Tomb of Buju' Adirasa.

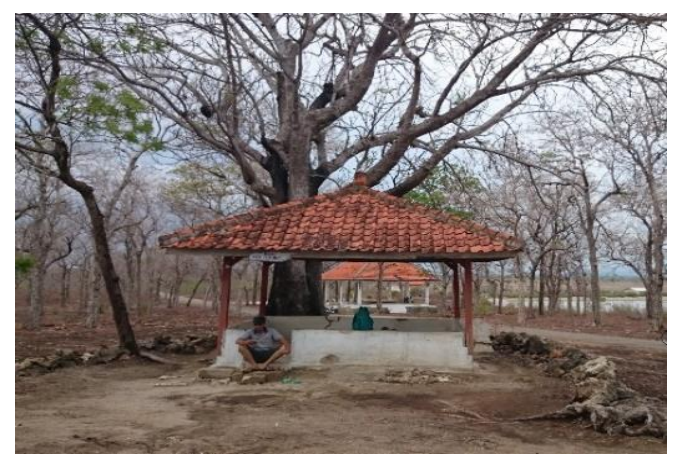

Figure 3. Historical Tomb of Buju' Adirasa Source: field survey, 2015

3. The Tradition of "Petik Laut"

Petik Laut is an expression of gratitude for livelihood and salvation given by God through the nature. This tradition is now used as cultural and traditional attraction of the fishermen community in Jumiang Beach Tourist Area and a means to explore the local potentials through local arts, various competitions, and traditional party with various entertainments (Figure 4).

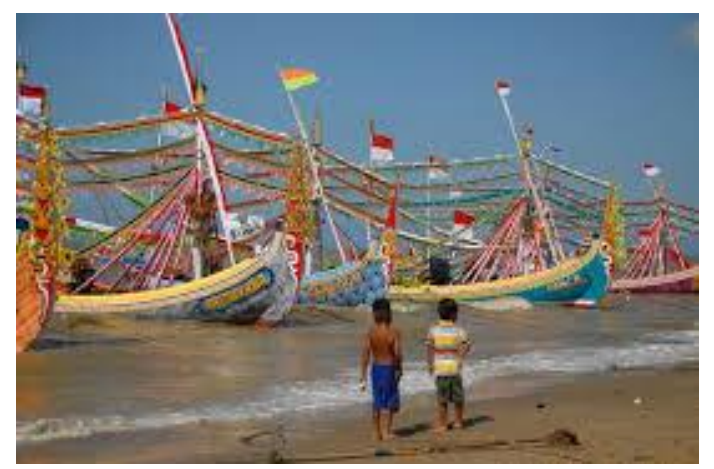

Figure 4. Ceremony of "Petik Laut" in 2014

Source: www.antaranews.com

4. Fisherman's Traditional Boats

Fisherman's traditional boats is one of supporting tourism attraction in Jumiang beach tourist area. Sailing through the sea by boat or ornamental fishing boats can be a short fun adventure for the tourists. While sailing through the sea, the 
tourists can enjoy the scenic beauty of the ocean and can fish in the middle of the sea (Figure 5).

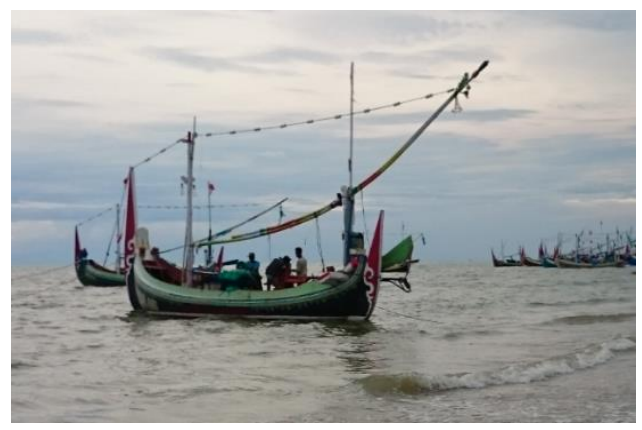

Figure 5. Ceremony of "Petik Laut" in 2014 Source: field survey, 2014

\section{Lorju' Culinary}

This coastal tourist area has a unique culinary with regional specialties that cannot be found in other areas. This is the potential of Jumiang Beach Tourist Area that distinguishes it from other beaches in Pamekasan.

6. Snacks of Jumiang Beach

Jumiang Beach Tourist Area has distinctive natural products, such as white anchovy (which is processed into anchovy chips) and seaweeds. These snacks can be another potential of this tourist area and must be developed into shopping facilities for the tourists.

7. The Natural Charm of Jumiang Forest Hills and Corral Cliffs

The wooded hill of Jumiang Beach provides shade and coolness for the tourists. The existence of the coastal cactus at the top of the cliffs and in between the rocks can become another unique natural potential of Jumiang Beach.

8. The Natural Beauty of Mangrove Forest

This tourist area is equipped with the mangrove forest which has 10 species of mangrove plants. This mangrove forest is of course another supporting attraction of the beach.

See the following Figure 6 to see the distribution all of tourism potentials in Jumiang Beach Tourist Area. 


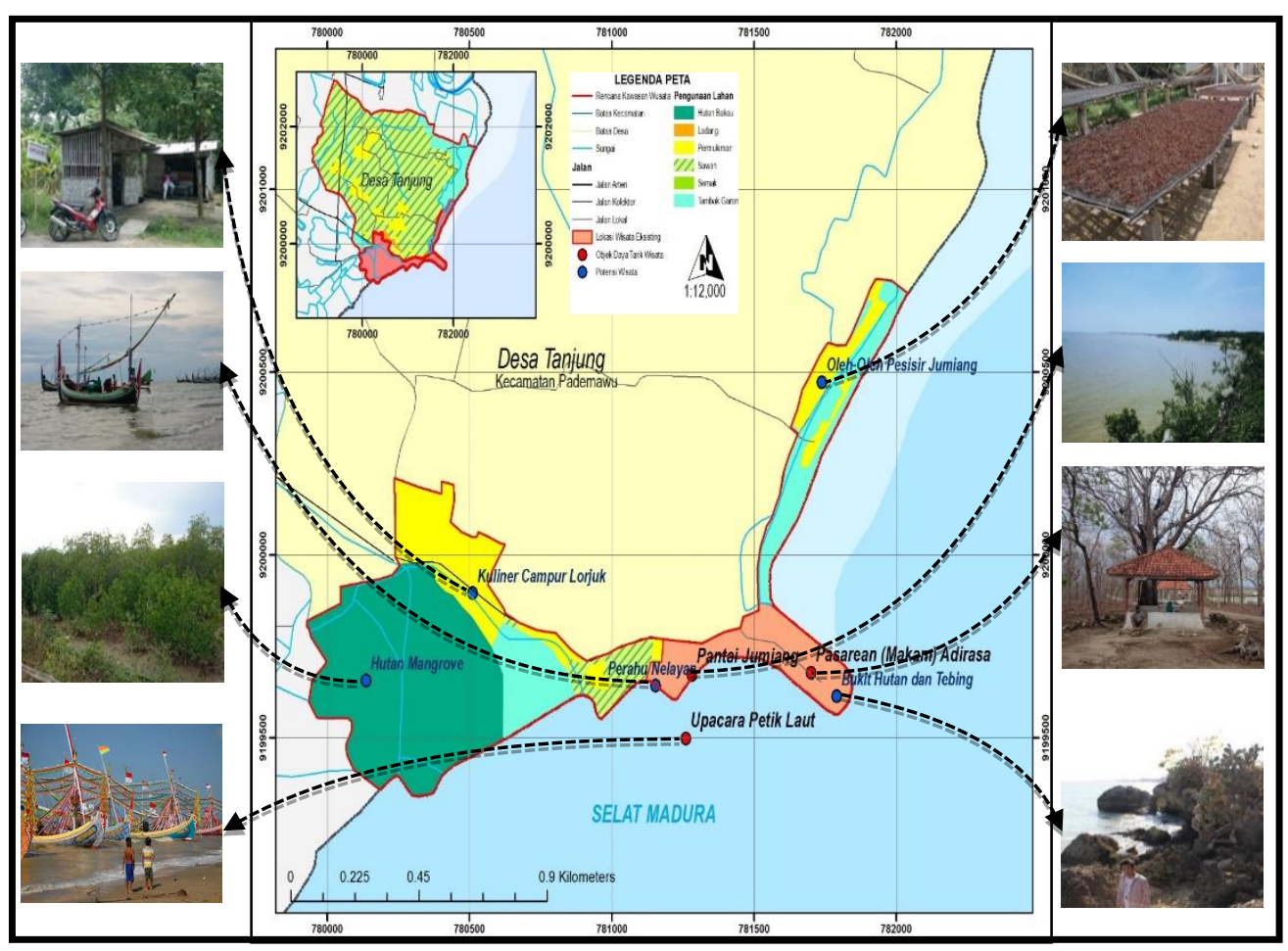

Figure 6. Potentials of Jumiang Beach Tourist Area Source: analysis results, 2015

\section{Analysis of Factors that Influence the Development of Jumiang Beach Tourist Area in Pamekasan District}

Analysis of factors that influence the development of Jumiang Beach Tourist Area in Pamekasan District using Content Analysis method is divided into some steps, as follows:

1. Results of Data Coding and Simplification

The results are based on in-depth interview transcripts of 6 (six) stakeholders. The coding stage aims to find a code that indicates an influence of a variable on the development of Jumiang Beach Tourist Area. Figure 7 is an example of the discovery of code in the transcript of interview.

Based on the quote in figure 7 , there is an analysis unit, i.e. sentence unit, uttered by stakeholder 1 (G1) which indicates that the variable of the presence of institutional managers of tourist areas (V.12) influences the development of Jumiang Beach Tourist Area because without a manager, Jumiang Beach Tourist Area is not optimally managed (V12.2) and the development activities cannot last longer (unsustainable) (V12.3). This indication shows that stakeholder 1 considers this variable is influential. Therefore, unit of analysis in the quotations above encoded as V12.2, because it has indicated the alleged influence of variables of the presence of the coastal tourist area manage (V12) by sequence repetition number 2 in the entire transcript of the interview as well as for V12.3 
code. The following is the tabulation matrix of coding result based on the statements of each stakeholder for each variable that is considered influential in the development of Jumiang Beach Tourist Area (Table 2).

G1 : Actually, it happened because of the lack of management, so that no one can organize Jumiang Beach to optimize the beach as well.

$\mathrm{R}$ : So, does Jumiang Beach lack of management, Sir?

G1 : True, there is no management. So we will leave it to whom? We want to build anything in that place but how about the continuatioan of management later? So, In my opinion, it will be useless if we already have built but there is no management, because it will be damage in next time.

Figure 7. Quote of Findings Code from Stakeholder G1 Source: In-Depth Interview, 2015

Table 2. Results of Each Variable Coding for Exploration Variables that Influence the Development of Jumiang Beach Coastal Tourist Area

\begin{tabular}{|c|c|c|c|c|c|}
\hline \multirow[t]{2}{*}{ No } & \multirow[t]{2}{*}{ Code of Variables } & \multicolumn{2}{|c|}{$\begin{array}{c}\text { Number Iteration of Unit } \\
\text { Analysis }\end{array}$} & \multicolumn{2}{|c|}{$\begin{array}{c}\text { Composition of } \\
\text { stakeholders agreement }\end{array}$} \\
\hline & & Influential & Not Influential & Influential & Not Influential \\
\hline 1 & $\begin{array}{l}\text { Types of coastal tourist } \\
\text { attraction }\end{array}$ & 45 & 0 & 6 & 0 \\
\hline 2 & $\begin{array}{l}\text { The uniqueness of } \\
\text { coastal tourist attraction }\end{array}$ & 19 & 0 & 6 & 0 \\
\hline 3 & $\begin{array}{l}\text { The existence of life } \\
\text { culture }\end{array}$ & 18 & 0 & 6 & 0 \\
\hline 4 & $\begin{array}{l}\text { The uniqueness of life } \\
\text { culture }\end{array}$ & 13 & 0 & 6 & 0 \\
\hline 5 & $\begin{array}{l}\text { Availability of } \\
\text { supporting utilities }\end{array}$ & 29 & 0 & 6 & 0 \\
\hline 6 & $\begin{array}{l}\text { Availability of service } \\
\text { facilities }\end{array}$ & 40 & 0 & 6 & 0 \\
\hline 7 & $\begin{array}{l}\text { Availability of transport } \\
\text { modes to tourist area }\end{array}$ & 0 & 11 & 0 & 6 \\
\hline 8 & Road networks & 0 & 9 & 0 & 6 \\
\hline 9 & $\begin{array}{l}\text { Local community } \\
\text { activities associated } \\
\text { with tourism activities }\end{array}$ & 46 & 0 & 6 & 0 \\
\hline 10 & $\begin{array}{l}\text { Local community } \\
\text { attitudes towards } \\
\text { tourists }\end{array}$ & 24 & 0 & 6 & 0 \\
\hline 11 & $\begin{array}{l}\text { Policies supporting the } \\
\text { development of coastal } \\
\text { tourist area }\end{array}$ & 14 & 7 & 4 & 2 \\
\hline 12 & $\begin{array}{l}\text { Presence of the coastal } \\
\text { tourist area manager }\end{array}$ & 45 & 0 & 6 & 0 \\
\hline
\end{tabular}


Table 2. Continue

\begin{tabular}{|c|c|c|c|c|c|}
\hline \multirow[t]{2}{*}{ No } & \multirow[t]{2}{*}{ Code of Variables } & \multicolumn{2}{|c|}{$\begin{array}{c}\text { Number Iteration of Unit } \\
\text { Analysis }\end{array}$} & \multicolumn{2}{|c|}{$\begin{array}{c}\text { Composition of } \\
\text { stakeholders agreement }\end{array}$} \\
\hline & & Influential & Not Influential & Influential & Not Influential \\
\hline 13 & $\begin{array}{l}\text { Presence of investment } \\
\text { opportunities for private } \\
\text { sectors }\end{array}$ & 21 & 0 & 6 & 0 \\
\hline 14 & $\begin{array}{l}\text { Marketing strategy of } \\
\text { coastal tourism }\end{array}$ & 24 & 0 & 6 & 0 \\
\hline 15 & $\begin{array}{l}\text { Improvement the } \\
\text { environmental hygiene } \\
\text { of coastal tourism }\end{array}$ & 16 & 0 & 6 & 0 \\
\hline 16 & $\begin{array}{l}\text { Improvement of human } \\
\text { resources in the coastal } \\
\text { tourist area }\end{array}$ & 40 & 0 & 6 & 0 \\
\hline 17 & $\begin{array}{l}\text { Proportion of people } \\
\text { working in tourism } \\
\text { sector }\end{array}$ & 0 & 10 & 0 & 6 \\
\hline 18 & $\begin{array}{l}\text { Level of public welfare } \\
\text { around the tourist area }\end{array}$ & 4 & 7 & 2 & 4 \\
\hline
\end{tabular}

Based on the table above, we can see clearly that there is a tendency of indication of the influence of a variable based on all stakeholders and the number of iterations of sentence units that represent a particular variable. From the results, we can see that the variable of types of coastal tourist attraction and the presence of the coastal tourist area manager are variables that are confirmed by all stakeholders and variables that are most often repeated in the entire transcript of the interview. Both variables are repeated 45 times in the entire transcript of the interview. This indicates that the two variables are the most dominant variables that influence the development of Jumiang Beach Tourist Area.

2. Result of Understanding Data

At the stage of data understanding, the result of data coding and simplification will be re-explored by looking at the conversational elements such as the speaking style of the stakeholders, namely by looking at the emotional condition and intonation in determining the significance of the influential variable on the development of Jumiang Beach Tourist Area. Thus, we can find the significance of a variable on the development of Jumiang Beach Tourist Area (Figure 8).

Based on the transcript excerpt, we can see that there is an increase of emotion in stakeholder 2 when stating the indication of influence of variable of the local community attitudes towards tourists (V10). It represents that the influence of variable of the local community attitudes towards tourists on the development of Jumiang Beach Tourist Area is significant, particularly its influence in the form of local community attitudes in treating tourists (V10.6) and interaction built between the local community and the tourists (V10.7) which will impact on how long the tourists will stay in the tourist area. See the following Table 3 to get 
more details about indication of the significance effect of development tourist area variables

G2 : I am sure that people around Jumiang Beach are very welcome to the visitors, both of domestic and foreign visitor. I am sure they are very welcome. It is important that there is an interaction between community around Jumiang Beach and the tourist for its future development. Because the convenience traveled is also determined by the attitudes and behaviour of local community. The convenience of_tourists is determined whether the social $\mathrm{V} 10.6$ interaction is good or not, serve the tourists or not, friendly to the tourists or not. That's the point. If the interaction can be established well, tourists will stay longer in Jumiang Beach (condition: increased intonation).

Figure 8. Quote of Findings Code from Stakeholder G2 Source: In-Depth Interview, 2015

Table 3. Indication of Significance Effect of Development Tourist Area Variables

\begin{tabular}{|c|c|c|c|c|c|c|c|}
\hline \multirow[t]{2}{*}{ No. } & \multirow[t]{2}{*}{ Variables } & \multicolumn{6}{|c|}{$\begin{array}{l}\text { Indication of the influence of each } \\
\text { variable from each stakeholder }\end{array}$} \\
\hline & & G1 & G2 & P1 & $\mathbf{P 2}$ & C1 & $\mathrm{C2}$ \\
\hline 1 & Types of coastal tourist attraction & SP & SP & SP & SP & SP & SP \\
\hline 2 & $\begin{array}{l}\text { The uniqueness of coastal tourist } \\
\text { attraction }\end{array}$ & SP & SP & SP & SP & SP & $\mathrm{P}$ \\
\hline 3 & The existence of life culture & SP & SP & $\mathrm{P}$ & PP & SP & SP \\
\hline 4 & The uniqueness of life culture & $\mathrm{P}$ & $\mathrm{P}$ & SP & $\mathrm{P}$ & SP & SP \\
\hline 5 & Availability of supporting utilities & SP & SP & SP & SP & SP & $\mathrm{P}$ \\
\hline 6 & Availability of service facilities & SP & SP & SP & SP & SP & SP \\
\hline 7 & $\begin{array}{l}\text { Availability of transport modes to } \\
\text { tourist area }\end{array}$ & $\mathrm{TP}$ & $\mathrm{TP}$ & $\mathrm{TP}$ & TPP & $\mathrm{TP}$ & $\mathrm{TP}$ \\
\hline 8 & Road networks & $\mathrm{TP}$ & TP & $\mathrm{TP}$ & $\mathrm{TP}$ & $\mathrm{TP}$ & $\mathrm{TP}$ \\
\hline 9 & $\begin{array}{l}\text { Local community activities } \\
\text { associated with tourism activities }\end{array}$ & SP & SP & SP & SP & SP & SP \\
\hline 10 & $\begin{array}{l}\text { Local community attitudes towards } \\
\text { tourists }\end{array}$ & SP & SP & SP & SP & SP & SP \\
\hline 11 & $\begin{array}{l}\text { Policies supporting the development } \\
\text { of coastal tourist area }\end{array}$ & SP & SP & SP & SP & $\mathrm{TP}$ & $\mathrm{TP}$ \\
\hline 12 & $\begin{array}{l}\text { Presence of the coastal tourist area } \\
\text { manager }\end{array}$ & SP & SP & SP & SP & SP & SP \\
\hline 13 & $\begin{array}{l}\text { Presence of investment } \\
\text { opportunities for private sectors }\end{array}$ & SP & $\mathrm{P}$ & SP & SP & SP & PP \\
\hline 14 & $\begin{array}{l}\text { Marketing strategy of coastal } \\
\text { tourism }\end{array}$ & SP & SP & SP & SP & $\mathrm{P}$ & SP \\
\hline 15 & $\begin{array}{l}\text { Improvement the environmental } \\
\text { hygiene of coastal tourism }\end{array}$ & $\mathrm{P}$ & $\mathrm{P}$ & $\mathrm{P}$ & $\mathrm{P}$ & SP & $\mathrm{SP}$ \\
\hline 16 & $\begin{array}{l}\text { Improvement of human resources in } \\
\text { coastal tourist area }\end{array}$ & PP & SP & SP & SP & SP & SP \\
\hline
\end{tabular}


Table 3. Continue

\begin{tabular}{|c|c|c|c|c|c|c|c|}
\hline \multirow[t]{2}{*}{ No. } & \multirow[t]{2}{*}{ Variables } & \multicolumn{6}{|c|}{$\begin{array}{c}\text { Indication of the influence of each } \\
\text { variable from each stakeholder }\end{array}$} \\
\hline & & G1 & G2 & P1 & $\mathbf{P 2}$ & C1 & $\mathrm{C2}$ \\
\hline 17 & $\begin{array}{l}\text { Proportion of people working in } \\
\text { tourism sector }\end{array}$ & TP & $\mathrm{TP}$ & TP & $\mathrm{TP}$ & TP & TP \\
\hline 18 & $\begin{array}{l}\text { Level of public welfare around the } \\
\text { tourist area }\end{array}$ & TP & TP & TP & TPP & PP & $\mathrm{P}$ \\
\hline \multicolumn{8}{|c|}{$\begin{array}{l}\text { Source: results of analysis, } 2015 \\
\text { Note: } \mathrm{SP}=\text { Very influential } \\
\mathrm{P}=\text { Influential } \\
\mathrm{P}=\text { Influential with consideration } \\
\mathrm{TP}=\text { Not Influential } \\
\text { TPP = Not Influential with conside }\end{array}$} \\
\hline
\end{tabular}

Based on overall results of data understanding, there is a tendency of stakeholders in determining the effect of a variable on development of Jumiang Beach Tourist Area. In general, a variable that is claimed to be influential is the variable which regards the tourist attraction, infrastructure and facilities, community participation, social and cultural aspect, and the institution of the tourist area. Types of coastal tourist attraction and the presence of institutional managers of tourist areas remains the most influential variable, because there is an increased intonation of all stakeholders in responding to indications of influence of these variables. Meanwhile, 4 (four) other variables don't have significant influence, because most of iterations of analysis unit are confirmed to be not influential, thus they do not need to be followed up to see the significance of their influence. Those 4 variables are the availability of transport modes to the tourist area (V.7); the road networks (V.8); the proportion of people working in the tourism sector (V1.7); and the level of public welfare around the tourist areas (V.18).

3. Narrating Process (Abstraction of Results)

The influential variables are re-analyzed inside the factors, in which each factor can be explained by a single variable or a combination of several variables that have the same characteristics or correlates in reference to a similar factor. The resulting factor has more specific characteristics which better describes the conditions in the study area. The details about the factors that influence the development of Jumiang Beach Tourist Area can be seen below:

a. Active participation of local community in tourism activities

This factor is explained by variables of community activities associated with tourism activities (V9) and community attitudes towards tourists (V10). Active participation of local community describes the potential of community activities that can support the development of Jumiang Beach Tourist Area, including sailing activities, seaweed cultivation, hawker, until tourism awareness group (Kelompok Sadar Wisata Jumiang). See the following Figure 9 to get an example of local community activities: see grass cultivation. 
Participation of local community is a kind of inputs in the development of coastal tourism. Through the participation of local community, they are expected to be able to develop existing activities in order to support tourism activities in Jumiang Beach and provided services and convenience for tourism activities. Consequently, tourism activity can provide direct benefits to local people and tourists want to stay long enough in Jumiang Beach Tourist Area.

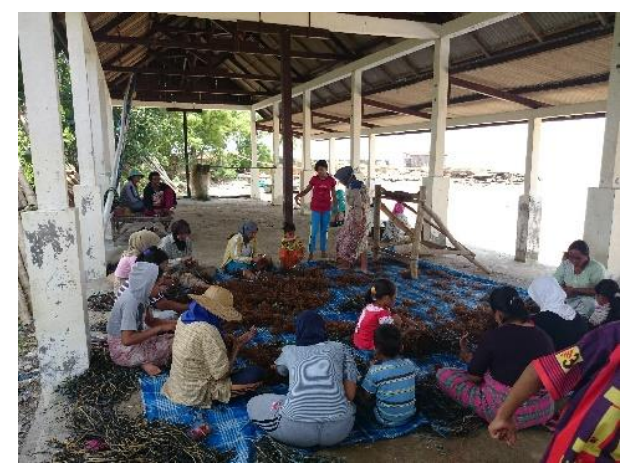

Figure 9. Sea Grass Cultivation Activity which can Support Tourism Activities Source: field survey, 2015

b. Improvement of coastal tourist attractions by utilizing the uniqueness in each tourist potential

This condition is explained by the variable of types of coastal tourist attraction (V1), the uniqueness of the coastal tourist attraction (V2), the existence of life culture (V3), and the uniqueness of life culture (V4). This factor describes that tourism attraction become a driving presence of tourists to a tourist destination. Within its very decisive position, then tourist attraction should be designed and managed in a professional manner so it can attract tourists to come. In facts, Jumiang Beach has great attraction of natural beauty and some supporting attractions, including cultural, religious, and culinary attractions, one of which is the uniqueness of Jumiang Forest Hills and Corral Cliffs (Figure 10). But, less attractive of innovation and tourist attractions makes the existing tourist potentials are less exploitable to create various types of activity that can be done by tourists. Therefore, this factor led to efforts to develop tourism potentials, by increasing or adding tourist attractions. The more attractions can be offered, the more able to attract tourists and make tourists more comfortable and interested to visit Jumiang Beach. 


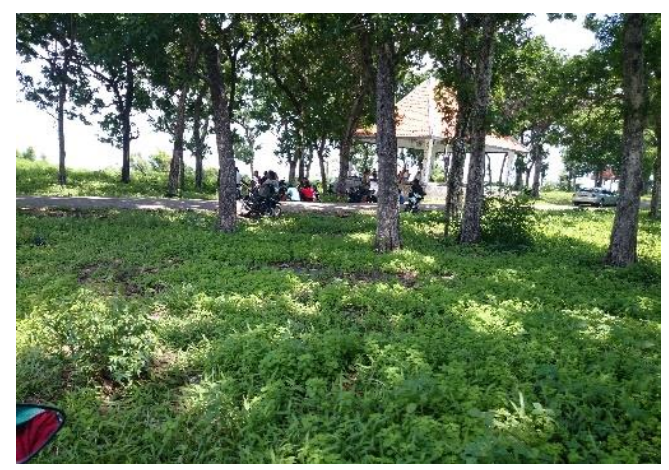

Figure 10. The Uniqueness of Jumiang Forest Hills and Corral Cliffs that can be Explored as Outbond Area Source: field survey, 2015

c. Presence of institutional managers of tourist areas

This factor is explained by the presence of institutional managers of tourist areas (V.12) and investment opportunities for the private sectors (V.13). The factor explains the performance of the management and service system through the presence of institutional managers to accelerate the development of tourist area. The attraction innovations and tourist attractions in Jumiang Beach Tourist Area can be more interesting and the development of infrastructure and supporting tourist facilities can be conducted by the presence of clear management institutions and participation of private sector. Efforts to improve system performance improvements in service, management, and maintenance of the tourism potential can be conducted by the presence of institutional management to revive the existing tourism potentials. Therefore, the presence of institutional managers to organize tourist activities become very influential factor in the development of Jumiang Beach Tourist Area.

d. Improvement the quality of local community in supporting tourist activities This factor is explained by variable of the improvement of the quality of the local community in the coastal tourist area (V16). The factor describes condition of the quality of human resources in Jumiang Beach Tourist Area in terms of knowledge and flow of information on tourism. It has implication on the level of skill in tourism businesses management. The paradigm among Pamekasan community which states that tourism will erode Islamic values and cultural values result in a negative perception of tourism development.

In development of Jumiang Beach tourist area, skill enhancement of local community is necessary, because tourism sector requires highly and professional skilled workforce. Besides, quality services that meet tourists' needs is a key indicator in tourism industry. Therefore, this factor led to efforts to improve the quality of local community through the strengthening of skills training, procedures for service in tourism activities, and tourism management. It also has influence in preparing qualified and quality human resources since 
the beginning, so that Jumiang people are ready to work in tourism industry or business in Jumiang Beach tourist area.

e. Improvement the quality and quantity of tourism infrastructure and facilities This factor describes the condition of basic infrastructure and tourism facilities in order to support the tourism development. It's explained by variable of the availability of coastal tourism supporting utilities (V5) and coastal tourism service facilities (V6). In Jumiang Beach, tourist convenience isn't maximally supported due to the lack of maintenance of tourism infrastructure and facilities (Figure 11). Basic infrastructure and facilities were initially and basically added values for Jumiang Beach Tourist Area, so that this factor is influential in improving service of tourism infrastructure and facilities to fulfill tourists' needs. They are indispensable to sustain the implementation of tourism development.

This factor shows that the development of tourist attraction when combined with the development of tourism facilities, such as the provision of accommodation and tourist transport facilities, will be able to increase the attractiveness for the growing number of tourists and supports the development of a new tourist attraction. Optimal results can be achieved if development efforts are supported by the development of adequate infrastructure (Figure 11). An adequate infrastructure and tourism facilities will create a good conditions and ready to compete with other tourist destination outside Pamekasan.

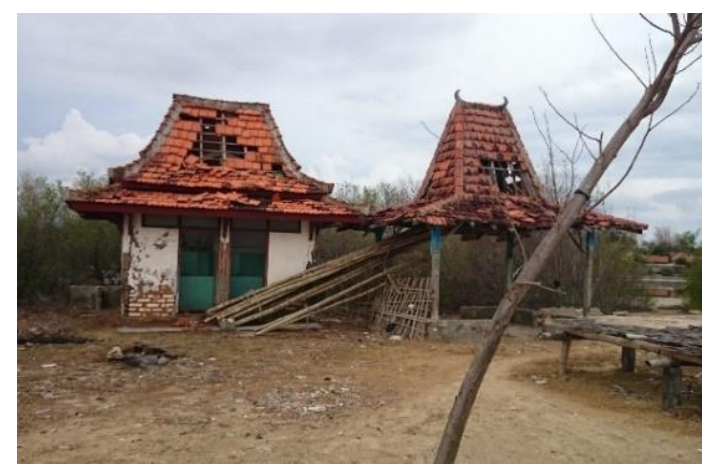

Figure 11. Sanitary Facilities that have been Damaged Source: field survey, 2015

f. Strengthening of marketing and promotion network quality

The factor describes the condition of the promotional efforts made to introduce the potential of Jumiang Beach Tourist Area. The conditions in Content Analysis is explained by variable of coastal tourism marketing strategy (V14). So far, promotional efforts made were limited on marketing strategy through web sites that are rarely updated. For Jumiang Beach tourist area that is still in the stage of introduction, the intensity of promotion must be improved in order to make tourists more aware of the existence attractions in this tourist area. The development of coastal tourism promotion activities can 
make people more familiar with the potential of coastal tourism which has not been much research to know the tourism potential of Jumiang Beach tourist Area. Therefore, strengthening of publication and promotion network quality becomes an influential factor in order to introduce Jumiang Beach to the wider community.

g. Maintenance and improvement of environmental sustainability in coastal tourist area

The factor describes condition of environmental improvement activities undertaken to preserve the environment. For Jumiang Beach Tourist Area which is a nature tourism, environmental sustainability, especially around tourist attraction, is very important and should be protected from various kinds of damage as well as decreased function and productivity. It because the main tourist activities in this area involve the surrounding environment, including enjoying the panorama, fishing, swimming, sailing, etc. The damage of environment due to the lack of environmental maintenance and improvement reduces the aesthetic value of tourist area and its marketability for the tourists. Therefore, this factor gives an impact on development of eco-friendly coastal tourism efforts, avoiding environmental pollution, and waste coastal natural resources. Besides, it secures both the preservation of natural resources and existing environment and prevention the disruption of ecosystems in order to guarantee good quality of life that remain for next generations.

h. Formulation of supporting policies related to spatial factors

This factor explains the formulation of supporting policies that govern the detailed provisions in tourist area especially related to spatial factors. It is explained by variable of policies supporting the development of the coastal tourist area (V11). Tourism development policy in Pamekasan is still in the form of Strategic Plan for Tourism Development Area. It means that the policy applies in macro for the tourism in Pamekasan. As a result, existing policy becomes less effective to implement the development efforts because each tourist area has different characteristics. Therefore, the development and management of object tourist attraction needs to be placed on the foundation of territorial integrity, which there are linkages between each tourism potentials in Jumiang Beach tourist area. The factor affirms that a tourist area is an integration of object tourist attraction which is determined by spatial factors. The formulation of supporting policies related to spatial factors could be an impulse for the emergence of a new ODTW (object tourist attraction), so the development of an ODTW is highly functional for the others ODTW.

\section{CONCLUSIONS}

Through Content Analysis, analysis process of the factors that influence the development of Jumiang Beach coastal tourist area can led to specific information. Those factors as follows:

1. Active participation of local community in tourism activities. This factor related to increasing local community's capability to develop existing activities in order 
to support tourism activities and provided services and convenience for tourism activities in Jumiang Beach.

2. Improvement of coastal tourist attractions by utilizing the uniqueness in each tourist potential. It leds to efforts to develop tourism potentials by increasing or adding tourist attractions

3. Presence of institutional managers of tourist areas to organize tourist activities in Jumiang beach tourist area

4. Improvement the quality of local community in supporting tourist activities. This factor led to efforts to improve the quality of local community, so that theay will be ready to work in tourism industry or business in Jumiang Beach tourist area.

5. Improvement the quality and quantity of tourism infrastructure and facilities. It is needed to fulfill tourists' needs and as a requirement to supports the development of Jumiang Beach tourist area

6. Strengthening of marketing and promotion network quality to make tourists more aware of the existence attractions in this tourist area

7. Maintenance and improvement of environmental sustainability in coastal tourist area. This factor has influence to protect Jumiang beach tourist area from various kinds of damage as well as decreased function and productivity

8. Formulation of supporting policies related to spatial factors to create linkages between each tourism potentials in Jumiang Beach tourist area on the foundation of territorial integrity

Stage of classification data in Content Analysis more facilitate the understanding of researchers towards the acquisition of data and information from interviews that are wide and varied. But at that stage requires foresight in finding specific words that give significance for researchers in understanding the case or issue. In the interview which involves many speakers should use special sostware to facilitate the discovery of specific sentences in the transcript of interview.

\section{REFERENCES}

Dinas Pariwisata, Pemuda \& Olah Raga, dan Kebudayaan Kabupaten Pamekasan (2012), Rencana Strategis Pengembangan Pariwisata Kabupaten Pamekasan, Disparporabud Kabupaten Pamekasan, Pamekasan.

Badan Perencanaan dan Pembangunan Daerah Kabupaten Pamekasan (2012), RTRW Kabupaten Pamekasan 2012-2032, Bappeda Kabupaten Pamekasan, Pamekasan.

Dinas Kebudayaan dan Pariwisata Provinsi Jawa Timur (2012), Kebudayaan dan Pariwisata Dalam Angka, Disbudpar Provinsi Jawa Timur, Jawa Timur.

Inskeep, E. (1991), Tourism Planning: An Integrated Sustainable Development Approach, Van Nostrand Reinhold, New York. 
This page intentionally left blank 